\title{
Habal and Murray 変法による声門閉鎖術
}

$$
\begin{aligned}
& \text { 森 一 功*, 山本 悦生** } \\
& \text { 竹林 恵子**, 田辺 正博*** }
\end{aligned}
$$

\section{Glottic Closure Using Modified Habal \& Murray's Method}

\author{
Kazunori Mori, M.D., ${ }^{*}$ Etsuo Yamamoto, M.D., ${ }^{* *}$ \\ Keiko Takebayashi, M.D., ${ }^{* *}$ and Masahiro Tanabe, M.D.*** \\ *Kyoto University, Kyoto, ${ }^{* *}$ Kobe Central Hospital, Kobe, and \\ *** Osaka Red Cross Hospital, Osaka
}

\begin{abstract}
Chronic aspiration is a serious condition causing life-threatening pneumonia. Various surgical procedures, such as tracheostomy, tracheo-esophageal anastomosis, supraglottic closure (epiglottic flap), glottic closure, and laryngectomy, have been performed in the treatment of aspiration. The reversibility of the air-way will be necessary when the patient recovers from underlying disorder. The epiglottic flap operation was considered to have such reversibility. We modified this technique and could obtain excellent results.

The surgical procedure was as follows: The mucosa of the edges of both the epiglottis and the aryepiglottic folds were removed to create a raw surface. The free edges of bilateral aryepiglottic folds were closed medially in layers with interrupted absorbable sutures. Then epiglottic edge was also sutured. At the top of epiglottis, epiglottic cartilage was resected properly and the membrane was sutured in layers. This technique was performed on two patients who were suffered from chronic aspiration and eliminated aspiration.
\end{abstract}

Key words : 声門閉鎖, Habal \& Murray 法

\section{I . 緒 言}

誤嚥防止の手術法は従来, 気管切開1), 喉頭切 断術 ${ }^{2 \sim 4}$, 喉頭へのステントの留置 ${ }^{5)}$, 喉頭全摘 術6)などがあるが，原疾患が改善したときに喉 頭機能が可逆的であることも必要と思われる。 この条件を満たしうる声門閉鎖術 (Montgomery 法7) がよく行われているが, 声带その ものへの侵襲があること, 後部声門の好置が難 しい等の問題点があり, 種々の変法が報告され

*京都大学医学部耳鼻咽喉科, **神戸市立中央市民病 院耳鼻科, ***大阪赤十字病院耳鼻咽喉科

別刷請求： $=606$ 京都市左京区聖護院川原町54 京都大学医学部耳鼻咽喉科 森 一功 投稿受付：1988年12月 4 日
ている。一方，声門上での声門閉鎖術（Habal and Murray 法 ${ }^{8)}$ ) は喉頭蓋を披裂喉頭蓋ひだに 縫合するもので，声帯にはさわらず，声閒閉鎖 の効果は確実で，手術手技は比較的容易とされ ている。

今回われわれはこの Habal and Murray 法 を一部変えた声門閉鎖を試み, 良好な結果を得 たので報告する。

\section{II . 手術法と症例}

頸部舌骨直上に約 $5 \mathrm{~cm}$ の水平皮膚切開をい れ，舌骨を露出する。舌骨に付着する筋群をで きるだけ切除した後, 舌骨中央部を約 $4 \mathrm{~cm}$ 切 除し, 咽頭内に入る。喉頭蓋先端を糸で率引し て声帯を明視下におく。披裂喉頭蓋ひだ，喉頭 
蓋の粘膜辺縁を切除し，下方から披裂喉頭蓋ひ だの内側外側粘膜を 2 層縫合した(図 1 )。さら に，喉頭蓋を左右であわせ，内側外側粘膜，軟 骨の 3 層縫合を行った(図 2 )。先端部は軟骨を 適宜切除して粘膜を縫合した。この方法で誤嬩 防止を行った 2 症例を以下に挙げる。

症例 168 歳男性で, 主訴は誤嬹。10年前, 前大脳動脈瘤破裂にてクリッピングによる根治 術, 切除頭蓋骨の人工頭蓋置換術を受け, 以後 右半身麻痺, 運動性失語の状態が続いている。 半年前の人工頭蓋部膿瘍除去術施行以後傾眠状 態で，誤嚥性肺炎を繰り返すようになった。喉 頭蓋はオメガ字型（図 3) をしており, 声帯の 動きは良好で嶼下は可能であるが，喉頭での反 射はほとんどない。

手術法: 気管切開の後, 全麻下に水平皮膚切 開を入れ，舌骨の中央部を切除して咽頭内に入 り (図 4), Habal \& Murray の方法に準じて 喉頭蓋，披裂喉頭蓋ひだの粘膜の辺縁を切除し て喉頭蓋を弁として縫い合わせようとしたが， 喉頭蓋がオメガ形をしていてうまく縫合できな いため, 披裂喉頭蓋ひだの左右をあわせ(図 5 ), 下方から縫い合わせていった。喉頭蓋も左右を あわせて正中で縫合した。先端は軟骨を切除し て粘膜ぞうしを縫い合わせて，閉鎖した。

術後 6 力月現在, 誤嚥は全くなく, 内視鏡で は円錐状になった喉頭蓋が見える(図 6 )。また, 気切口からの声帯の観察では声帯の内外転が認 められた。

この方法で結果が良好であったため，オメガ 字形でない喉頭蓋に対しても行ってみた。

症例 255 歳男性で, 主訴は誤嚥。3 力月前 転落事故で頸䯣損傷となり, 頸部以下の運動, 感覚ともに麻痺している。2 カ月前の頸椎前方 固定術施行以後嚥下はできず, 誤嚥性肺炎が続 く状態である。喉頭蓋はほぼ半円形をしていた。 また両側反回神経麻痺で, 喉頭での反射は全く なかった。とりあえず誤嚥防止のために声門閉 鎖を試みた。

手術法：同様のアプローチで咽頭内に入っ た。喉頭蓋は半円形をしていたので, 喉頭蓋が 円錐状となるように喉頭蓋軟骨を適宜切除した 後, 左右の披裂喉頭蓋ひだを縫い合わせ, 喉頭 蓋の左右の切除部分を内側粘膜, 軟骨, 外側粘

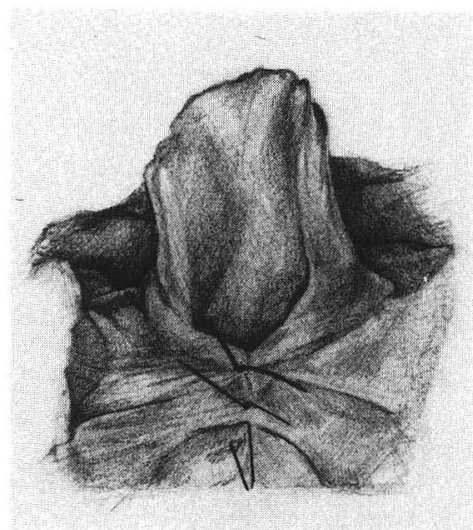

図 1 披裂喉頭蓋ひだを正中で縫合

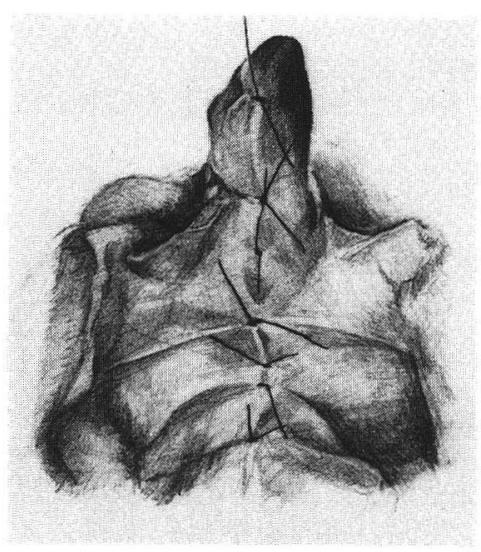

図 2 喉頭蓋も正中で縫合

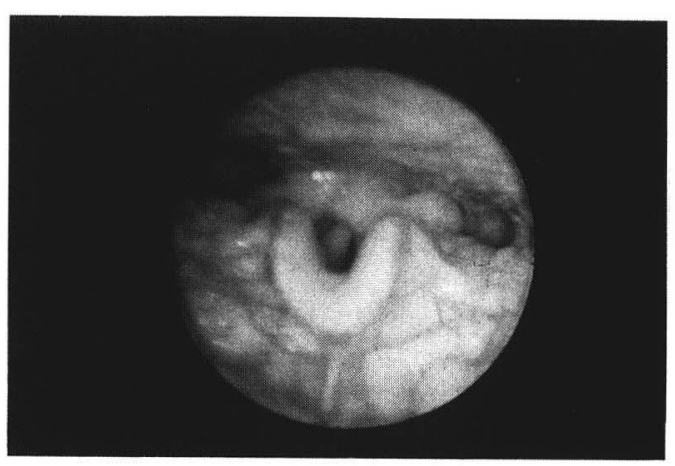

図3 症例 1 の喉頭蓋 


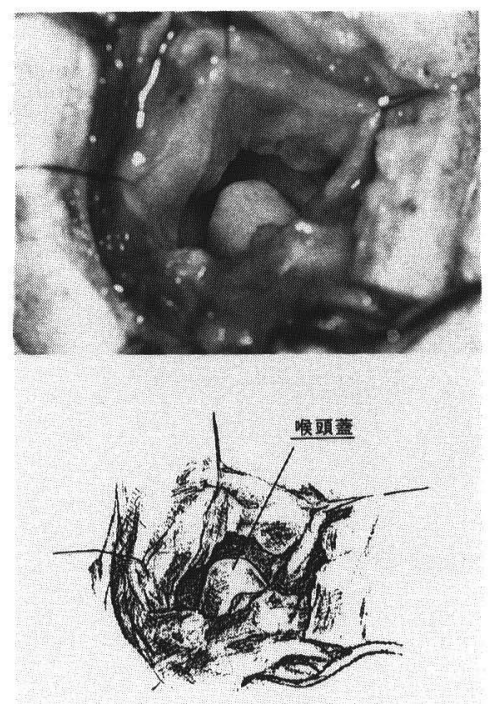

図 4 症例 1 の術中所見

舌骨を切除して咽頭内に入る。喉頭蓋が見える。

膜の 3 重に縫合した。

術後 4 力月現在, 喉頭への唾液の流入はまっ たくみられない。

\section{III. 考 按}

従来誤嚥防止の効果が確実で機能回復が可能 ということで，慢性的な誤嬹に対しては声門閉 鎖術がよく行われている。声門閉鎖術には声带 レベルで閉鎖する Montgomery の方法7,9,10) と, 声門上レベルで喉頭蓋を披裂喉頭蓋ひだに縫い 合わせて, 文字どおり蓋をしてしまう Habal \& Murray の方法8,11,12) とがある。うち, Habal \& Murray 法は 7 例の手術例が報告 ${ }^{11}$ され, 機能 再建の成功例も報告されている。

今回われわれは最初 Habal \& Murrayの方 法で声門閉鎖を試みた。Habal \& Murray の原 法は喉頭蓋を後方へ倒し込んで喉頭蓋先端と披 裂間部とが接するように縫合するものである。 が, オメガ字型の喉頭蓋では喉頭蓋軟骨の弾性 が強くてこの縫合が不可能であり，われわれは 披裂喉頭蓋ひだ，喉頭蓋を垂直方向に縫合して いくことを考えた。嚥下反射の際には喉頭が挙 上して両側仮声帯が正中に近づくから，両側披 裂喉頭蓋ひだを正中で縫合することは困難では

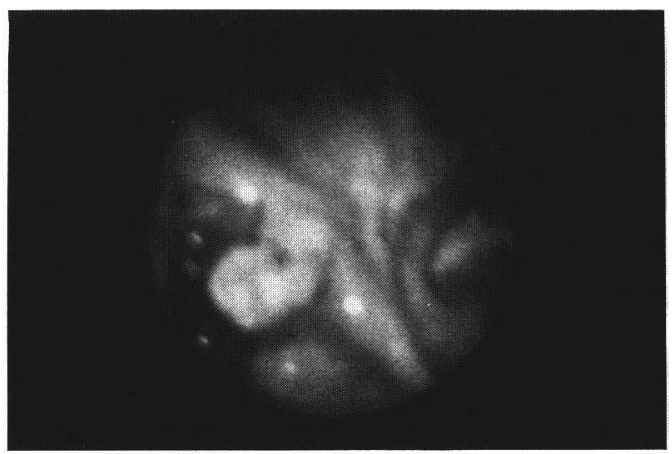

図 6 術後の喉頭蓋

なかった。

また，半円形の喉頭蓋でも喉頭蓋軟骨から粘 膜を剝離して喉頭蓋軟骨を一部切除することで 変形しやすくすることができた。下方から縫合 していくと喉頭蓋は円錐状となるが，その先端 部では軟骨を切除して, 内外粘膜を 2 層縫合す ることで十分閉鎖しえた。

本法は従来の方法に比べ，喉頭蓋を牽引する ことで視野を十分広くとれ，咽頭切開部に近い ところで操作できるため縫合が容易であり，ま た喉頭蓋が円錐状になるため，その効果は確実 であるという利点があると考えられた。Habal \& Murray の方法での声門閉鎖が難しい場合, 本方法を試みてもよいものと思われた。 


\section{IV. ま と め}

Habal \& Murray 変法による声門閉鎖の一 方法を報告し, 確実な誤嬩防止効果が得られる ことを示した。

稿を終えるにあたり，御校閲いただきました本庄 㦑教授に深謝致します。

本論文の要旨は第40回日本気管食道科学会にてロ 演した。

\section{文献}

1) Sasaki, C.T., Suzuki, M., Horiuchi, M., et al. : The effect of tracheostomy on the laryngeal closure reflex. Laryngoscope, $87: 1428-1430$, 1977.

2 ) Lindeman, R.C. : Diverting the paralyzed larynx: A reversible procedure for intractable aspiration. Laryngoscope, $85:$ 157-180, 1975.

3 ) Lindeman, R.C., Yarrington, C.T., and Sutton, D.: Clinical experience with tracheoesophageal anastomosis for intractable aspiration. Ann. Otol., 85: 609-612, 1976.

4) Baron, B.C., and Dedo, H.H. : Separation of the larynx and trachea for intractable aspiration. Laryngoscope, 90:1927-1932, 1980.

5 ) Weisberger, E.C., and Huebsch, S.A. : Endos- copic treatment of aspiration using a laryngeal stent. Otolaryngol. Head Neck Surg., 90:215-222, 1982.

6) Cannon, C.R., and McLean, W.C.: Laryngectomy for chronic aspiration. Am.J. Otolaryngol., $3: 145-149,1982$.

7) Montgomery, W.W.: Surgery to prevent aspiration. Arch. Otolaryngol., $101: 679-682$, 1975.

8) Habal, M.A., and Murray, J.E.: Surgical treatment of life-endangering chronic aspiration pneumonia. J. Plast. Reconstr. Surg., 49:305-311, 1972.

9) Lulenski, G.C.: Laryngeal closure and glottic reconstruction. Ear Nose Throat J., 59:2330, 1980.

10) Sasaki, C.T., Milmoe, G., and Yanagisawa, E. : Surgical closure of the larynx for intractable aspiration. Arch. Otolaryngol., $106: 422-423,1980$.

11) Vecchione, T.K., Habal, M.A., and Murray, J. E. : Further experiences with the arytenoidepiglottic flap for chronic aspiration pneumonia. Plast. Reconstr. Surg., $55: 318$ 323, 1975.

12) Strome, M., and Fried, M.P.: Rehabilitative surgery for aspiration. Arch. Otolaryngol., $109: 809-811,1983$. 